\title{
Expression of p21 WAF1/CIP1/SD11 and p53 in Apoptotic Cells in the Adrenal Cortex and Induction by Ischemia/Reperfusion Injury
}

\author{
Vladimir V. Didenko, Xiangdong Wang, Lianqing Yang, and Peter J. Hornsby \\ Huffington Center on Aging and Department of Cell Biology, Baylor College of Medicine, Houston, Texas 77030
}

\begin{abstract}
$\mathrm{p} 21^{\mathrm{WAF} 1 / \mathrm{CIP} 1 / \mathrm{SDI} 1}$, an inhibitor of cyclin-dependent kinases, is expressed at varying levels in human adrenal glands removed during surgery or organ recovery. In glands with p21 mRNA, nuclear p21 immunoreactivity, which was occasionally extensive, colocalized with p53 immunoreactivity and DNA damage, as evidenced by in situ end-labeling. Many cells showed morphological features of apoptosis when observed by fluorescent DNA dye staining and electron microscopy. This pattern was also associated with high levels of cytoplasmic heat shock protein 70. To address the question of the origin of p21 expression in some human adrenal glands, rat adrenal glands were subjected to $30 \mathrm{~min}$ of ischemia followed by $8 \mathrm{~h}$ of reperfusion. Cells with nuclear p21 and p53 appeared in the adrenal cortex together with DNA damage detected by in situ end-labeling. Nuclear p21 immunoreactivity was also produced in adrenal tissue fragments incubated at $37^{\circ} \mathrm{C}$ in vitro. However, in this case, p21 expression was confined to the cut edge of the tissue. In contrast, p21 in human adrenal glands, as in ischemic rat glands, was within the inner regions of the cortex, supporting an origin of the protein in vivo rather than postmortem. The $\mathrm{p53/p21}$ pathway of reaction to cellular injury, potentially leading to apoptosis, may play a role in tissue damage such as that resulting from ischemia/reperfusion. In the human adrenal cortex this process may be a precursor of adrenal failure. (J. Clin. Invest. 1996. 97:1723-1731.) Key words: cell death - cyclin-dependent kinases - tumor suppressor genes $\bullet$ heat shock proteins $\bullet$ immunohistochemistry
\end{abstract}

\section{Introduction}

$\mathrm{p} 21^{\mathrm{WAF} 1 / \mathrm{CIP} 1 / \mathrm{SDI} 1}$ is an important regulator of the cell cycle which acts by binding and inhibiting several cyclin-dependent kinase/cyclin complexes (1-5). It is expressed at high levels in human fibroblasts when they become senescent in culture (5, $6)$. Two divergent roles for p21 have been described. In the first it acts as the central downstream effector of the growth inhibitory effect of p53 which has been activated by damage to DNA or other means (7-11). The block of the cell cycle is hypothesized to allow time for the cell to repair its damaged DNA before entering S phase (12-14), yet it has also been

Address correspondence to Peter J. Hornsby, Ph.D., Huffington Center on Aging, Baylor College of Medicine, One Baylor Plaza M320, Houston, TX 77030. Phone: 713-798-7334; FAX: 713-798-6688.

Received for publication 2 October 1995 and accepted in revised form 16 January 1996.

J. Clin. Invest.

(C) The American Society for Clinical Investigation, Inc.

0021-9738/96/04/1723/09 \$2.00

Volume 97, Number 7, April 1996, 1723-1731 noted that apoptotic cells may express p21 $(15,16)$. Additionally, high expression of p21 accompanies the cessation of proliferation in some terminally differentiating cell types, both in experimental cell culture systems and during embryonic development in vivo, a role which does not require the participation of p53 (17).

Previously, we observed elevated expression of p21 in human and bovine adrenocortical cells as soon as they are dissociated from the intact tissue in preparation for cell culture (18). Increased p $21 \mathrm{mRNA}$ and protein was observed as early as $3 \mathrm{~h}$ after the start of the tissue dissociation procedure, consistent with the rapid induction of $\mathrm{p} 21$ by some DNA-damaging agents (7). Expression was maintained during plating in culture and subsequent long-term growth. It appears that tissue dissociation and placement in culture initiates a form of damage response in this differentiated cell type, even though most cells are viable and proliferate rapidly after plating. In contrast, despite the evident function of p21 as an important inhibitor of the cell cycle, the proliferation status of the cells was unrelated to p21 levels. The normal bovine, human, and rat adrenal cortex did not show p21 expression by mRNA, protein, or immunohistochemistry (reference 18 and our unpublished observations). Except during tissue regeneration, the adrenal cortex in vivo is a mitotically quiescent tissue with a low level of cell renewal (19). p21 in adrenocortical cells in culture was also unaffected by mitotic quiescence resulting from the withdrawal of a mitogen, FGF (18).

The role of p21 as a key element in the cascade of events initiated by DNA damage and other forms of cellular injury has been elucidated mainly from experiments on cells in culture. That it likely plays the same protective role in human tissues in vivo is evidenced by its induction in skin, after both ultraviolet irradiation, associated with appearance of nuclear p53 (16, 20), and chemical and mechanical injury (21). Apart from these instances, the extent to which the reaction to cellular injury involving the p53-dependent expression of p21 is active under conditions in organs in vivo is not yet clear. In these experiments we show that p53-associated induction of p21 occurs in the adrenal cortex in vivo. This work was initiated as a continuation of the observation of the rapid increase in p21 in adrenocortical cells placed in culture. The level of p21 in human adrenal glands was unexpectedly very variable, sometimes reaching levels similar to those of the cultured cells. By reproducing the induction of p21 in the rat adrenal cortex by ischemia/reperfusion, we support the hypothesis that the variable expression in the human adrenal cortex likely results from this or other forms of cellular injury which have occurred in vivo before surgical removal of the gland.

\section{Methods}

Human adrenal tissues. Human adrenal glands were obtained through the Cooperative Human Tissue Network and through the courtesy of Dr. Juan Lechago (Methodist Hospital, Department of Pathology, 
Houston, TX). Glands were obtained either at surgery, usually nephrectomy plus adrenalectomy for removal of a kidney tumor, or during recovery of the kidneys from organ donors for potential transplantation. Adrenal glands obtained from nephrectomies were placed in cold saline for transport to the laboratory. Adrenal glands removed with kidneys for transplantation had been perfused with cold University of Wisconsin solution (22) before organ recovery and were transported on ice in the same solution. Pieces of glands were fixed in paraformaldehyde or processed for preparation of RNA, as described below, without allowing an increase in temperature of the tissue.

Cell culture. Human and rat adrenocortical cells were cultured according to previously published procedures (23). Fetal adrenal glands were obtained from the Central Laboratory for Human Embryology of the University of Washington, Seattle. Cell suspensions were derived by enzymatic and mechanical dissociation of freshly obtained tissue ( $3 \mathrm{~h}$ of incubation with $1 \mathrm{mg} / \mathrm{ml}$ type I-A collagenase and $0.1 \mathrm{mg} / \mathrm{ml}$ DNase, both from Sigma Chemical Co., St. Louis, MO). The standard culture medium used was Dulbecco's Eagle's medium/ Ham's F-12 1:1 with $10 \%$ fetal bovine serum, 10\% horse serum, and $0.1 \mathrm{ng} / \mathrm{ml}$ recombinant basic FGF (Mallinckrodt Specialty Chemicals, Chesterfield, MO). This was supplemented with $1 \%$ vol/vol UltroSer $\mathrm{G}$ (IBF Technics, Savage, MD), a mixture of growth factors, as previously described (24). Population doubling levels (PDLs) ${ }^{1}$ were calculated according to reference 25 .

Probes and Northern blotting. Human $\mathrm{p} 21^{\mathrm{SDI} 1} \mathrm{cDNA}$ was from J.R. Smith (5). The homologous mouse cDNA, here used to probe rat RNA, was kindly supplied by S.J. Elledge (17). Probes for differentiated function genes were generously supplied as follows: human $17 \alpha-$ hydroxylase (CYP17), E.R. Simpson (26); rat cholesterol side-chain cleavage enzyme (CYP11A) cDNA, J.S. Richards (27); rat tyrosine hydroxylase cDNA, K.L. O'Malley (28). The preparation of total RNA from cultured cells, Northern blotting, and probe labeling were performed using previously established techniques (29). RNA was prepared from human and animal adrenal glands by immediate immersion of dissected tissue into cold RNAzol (Biotecx Laboratories, Houston, TX) followed by freezing in liquid nitrogen for storage. On thawing, the tissue was homogenized in RNAzol using a Teflon/glass motor-driven homogenizer, followed by RNA preparation in accordance with the manufacturer's directions. Blots were reprobed after washing in $85^{\circ} \mathrm{C}$ water. An oligonucleotide complementary to human ribosomal 28S RNA used to test for loading was purchased from Oncogene Science Inc. (Manhasset, NY) and was labeled with ${ }^{32} \mathrm{P}$ using polynucleotide kinase.

Immunohistochemistry. Tissues were fixed in $4 \%$ paraformaldehyde, dehydrated, and embedded in paraffin. 6- $\mu \mathrm{m}$ sections were deparaffinized and rehydrated using graded alcohol concentrations. Antigen retrieval was performed by incubation in prewarmed $100 \mathrm{mM}$ sodium citrate, $\mathrm{pH} 6.0$, at $90^{\circ} \mathrm{C}$ for $15 \mathrm{~min}$. After blocking nonspecific binding with sheep serum for $30 \mathrm{~min}$, sections were incubated in the primary antibody for $16 \mathrm{~h}$ at $4^{\circ} \mathrm{C}$. Human and bovine adrenal gland sections were probed with the following antibodies: anti-human p21 mouse mAbs EA10 (Oncogene Science Inc.) (16) and 6B6 (Pharmingen, San Diego, CA) both at 1:100 dilution; rabbit polyclonal against a GST-p21 fusion protein (Oncogene Science Inc.); monoclonal D07 recognizing both wild-type and mutant human p53 (Vector Labs, Inc., Burlingame, CA) at 1:30 dilution; monoclonal MIB-1 against Ki-67 antigen (Immunotech Inc., Westbrook, ME) at 1:100 dilution. Rat adrenal sections were probed with anti-p21 monoclonal antibody CP36 (30), a gift of E. Harlow, used at 1:10 dilution, and anti-mutant human p53 (PAb-240; Oncogene Science Inc.), which recognizes wildtype rat $\mathrm{p} 53$ in paraformaldehyde-fixed tissues (31). Staining was

1. Abbreviations used in this paper: CYP11A, gene symbol for cholesterol side-chain cleavage enzyme; CYP17, gene symbol for steroid $17 \alpha$-hydroxylase; ISEL, in situ end-labeling; PDL, population doubling level. achieved using an alkaline phosphatase-sheep anti-mouse Fab fragment conjugate (Boehringer Mannheim Corp., Indianapolis, IN) followed by incubation with the chromogens 5-bromo-4-chloro-3indolyl phosphate and nitro blue tetrazolium using the procedure recommended by the manufacturer.

Investigation of DNA damage and apoptosis. In situ end-labeling (ISEL) of $3^{\prime}$ ends of DNA by terminal deoxynucleotidyl transferase was performed on deparaffinized sections as described (32) with the use of digoxigenin-dUTP (Boehringer Mannheim Corp.) at $20 \mu \mathrm{M}$ instead of biotinylated dUTP. Digoxigenin-labeled DNA was detected with a sheep anti-digoxigenin Fab fragment-alkaline phosphatase conjugate (Boehringer Mannheim Corp.) and staining as described above. For visualization of chromatin by DNA-binding dye fluorescence, deparaffinized sections were incubated for $60 \mathrm{~min}$ in $0.5 \mu \mathrm{g} / \mathrm{ml}$ 4',6-diamidino-2-phenyl indole (DAPI) followed by washing and observation by fluorescence microscopy (33). For ultrastructural studies of cellular morphology, fragments of tissue were removed from the paraffin blocks (prepared as described above), deparaffinized, and processed for electron microscopy by standard methods using postfixation in $1 \%$ osmium tetroxide and uranyl acetate staining.

Ischemia/reperfusion in the rat adrenal gland. All procedures were approved by the Animal Care Committee of Baylor College of Medicine. Fischer 344 or Sprague-Dawley rats (male, 100-150 grams of body weight) were used with equivalent results. Under anesthesia, the peritoneal cavity was opened and the left renal artery was ligated adjacent to the aorta, using 4-0 surgical silk tied around the artery and a short length of 1-mm polyester tubing. Ischemia was monitored by loss and gain of color of the affected organs (adrenal gland and kidney). After $30 \mathrm{~min}$ the ligation was removed. This time was selected based on a previous report that $30 \mathrm{~min}$ of ischemia followed by reperfusion produced small $(0.1-0.5-\mathrm{mm})$ infarcts in the inner rat adrenal cortex (34). After $8 \mathrm{~h}$ animals were killed and tissues were either immediately fixed in paraformaldehyde or placed in RNAzol, as described above.
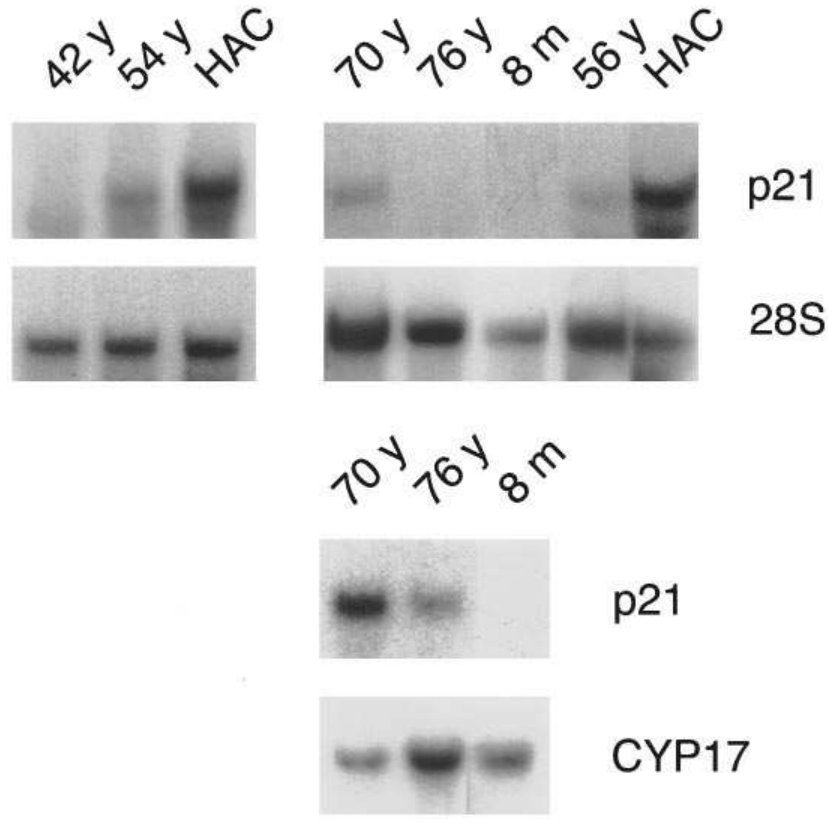

Figure 1. p21 mRNA levels in the human adrenal cortex. RNA was prepared from adrenal tissue from donors of the indicated ages $(y$, years; $m$, months). Levels were compared with those in cultured fetal human adrenocortical cells $(H A C)$. Normalization for RNA loading was performed by rehybridization with probes for $28 \mathrm{~S}$ ribosomal RNA or CYP17 (steroid 17 $\alpha$-hydroxylase). 

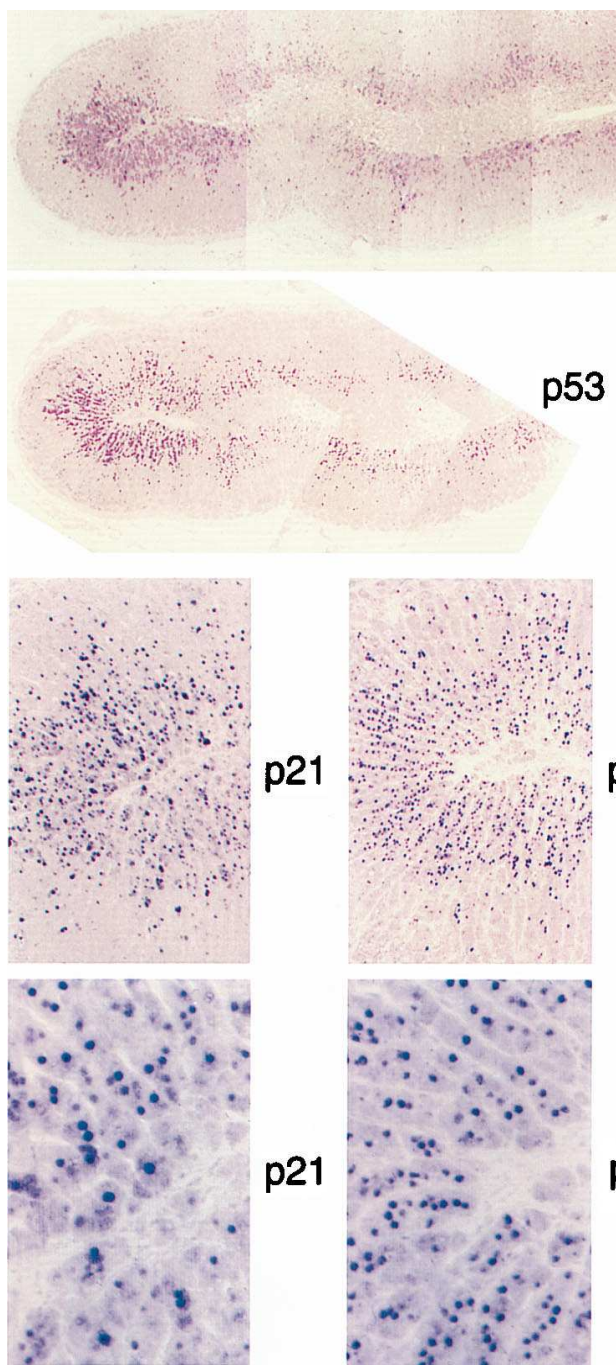

p21

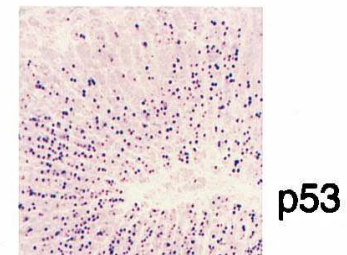

p21

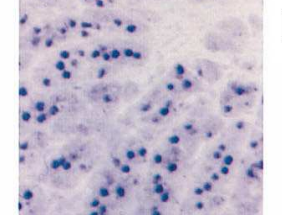

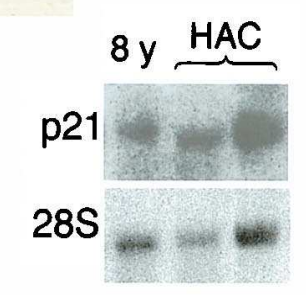

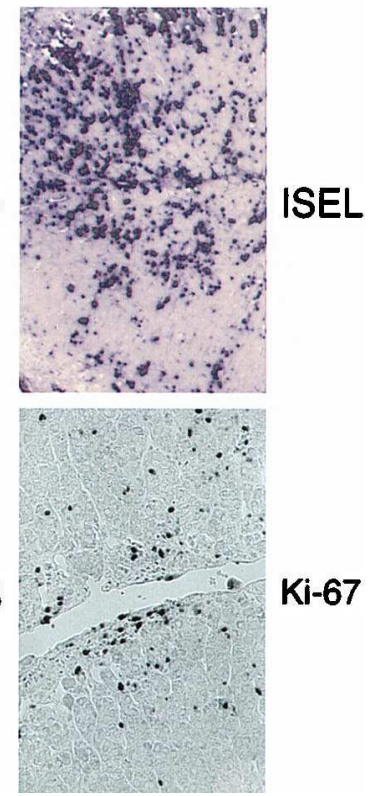

Figure 2. Patterns of p 21 and $\mathrm{p} 53$ in a human adrenal gland. The gland was obtained from an 8-yr-old male organ donor and was fixed and processed as described in the text. A Northern blot shows p21 mRNA and compares the level with that in cultured fetal human adrenocortical cells $(H A C)$. The upper composite photomicrographs (original magnification $\times 40$ ) show immunoreactivity with monoclonal antibodies against p21 and p53. Below are $\times 100$ and $\times 400$ magnifications of portions of the same sections. Additionally, the reaction product of ISEL of the same specimen is shown and an area of the gland with several cells showing Ki-67 immunoreactivity.

\section{Results}

In preliminary experiments, we examined p21 mRNA levels in a variety of adrenocortical tissue specimens from donors of different ages. The level of p21 mRNA varied widely (Fig. 1). We showed previously that fetal adrenocortical tissue, which ini-
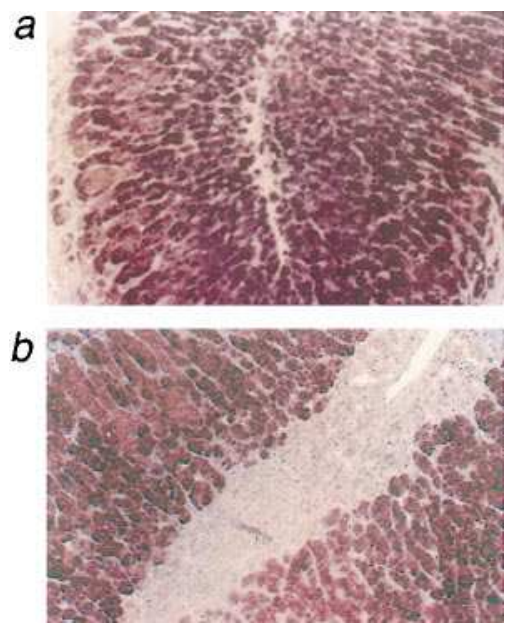

Figure 3. Human adrenal gland expression of hsp70; same tissue specimen as in Fig. 2. $a$ shows intense immunoreactivity in the end portion of the cortex; $b$ shows that immunoreactivity is confined to the cortex of the gland and does not extend to the medulla. tially had only a very low level of p21 mRNA, showed an immediate increase when the cells were dissociated from the tissue and placed in culture (18). RNA from cultured fetal human adrenocortical cells served as a positive control for $\mathrm{p} 21$ mRNA in this experiment. Some tissue samples from postnatal donors did not express p21 and others had levels that varied up to the level in cultured fetal adrenal cells. This large range of expression was observed when RNA loading of the blots was normalized either with a probe specific for adrenocortical cells (steroid $17 \alpha$-hydroxylase, CYP17) or with a $28 \mathrm{~S}$ ribosomal RNA probe.

Because some of the p21 mRNA-positive tissue samples were obtained from older donors, the expression of p21 initially appeared to be an age-related phenomenon. However, we were able to obtain a small number of tissue samples from much younger donors and some of these had high levels of p21 mRNA. One such tissue sample, from an 8-yr-old donor, was studied by Northern blotting and immunohistochemistry (Fig. 2). In this gland we observed abundant nuclear expression of p21 in the inner part of the cortex. Most p21-positive adrenocortical cells were at the ends of the characteristic cords of cells of the cortex where they contact the medulla or the alar raphe (35), the midline linear venous drainage region between two opposing layers of cortex in the parts of the gland where no 


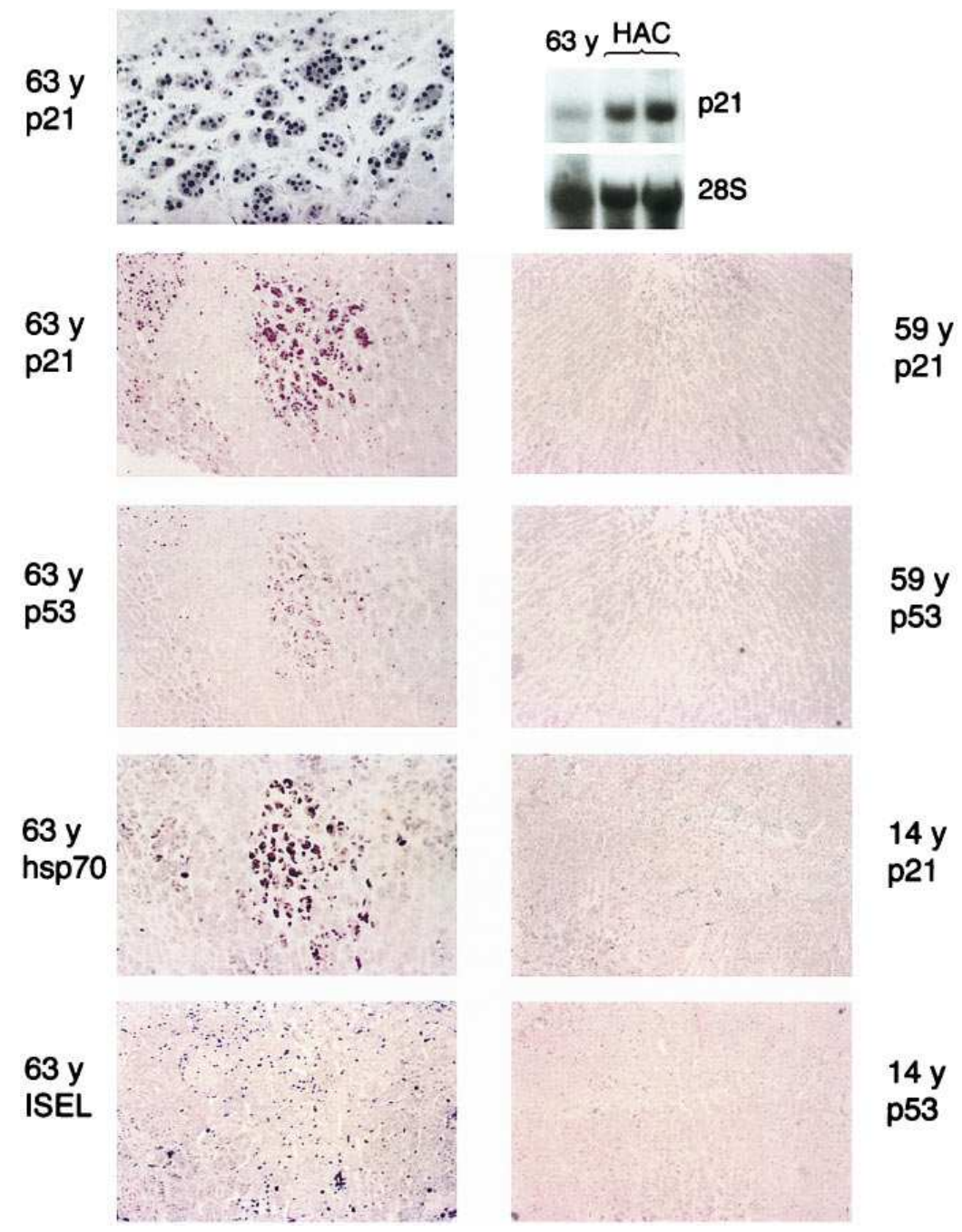

Figure 4. Patterns of p21, p53, hsp70, and ISEL in human adrenal glands. Glands were obtained from donors of the indicated ages and were fixed and processed as described in the text. For the 63-yr-old donor a Northern blot is shown (top right); an area of p21 immunoreactivity (top left; original magnification $\times 200$ ); another area stained for p21, p53, hsp70, and ISEL (left; original magnification $\times 100$ ). For the 14and 56-yr-old donors, which did not show p21 mRNA, results of antibody staining for $\mathrm{p} 21$ and $\mathrm{p} 53$ are shown (right; original magnification $\times 100$ ).

medulla is present. Some endothelial cells adjacent to adrenocortical cells also showed nuclear p21. Occasional positive cells were noted in the outer cortex, but the medulla was entirely negative, both in chromaffin cells and other cell types. Identical patterns were obtained with two different monoclonal antibodies against p21; additionally, a rabbit polyclonal antibody showed the same pattern but with more nonspecific background staining.

Because of the known role of $\mathrm{p} 21$ as a mediator of the antiproliferative effects of $\mathrm{p} 53$, we examined the pattern of $\mathrm{p} 53 \mathrm{ex}$ pression in this p21-positive adrenal gland. Using an anti-p53 monoclonal antibody which recognizes both normal and mutant forms of this molecule, we found a pattern of p53 immunoreactivity essentially identical to that of p21 (Fig. 2).

The similar patterns of p21 and p53 immunostaining suggested the involvement of DNA damage. DNA damage of various types has been shown to activate p53 and induce p21 (7, 14, 36, 37); moreover in some circumstances (e.g., in sebaceous glands) apoptotic cells express p21 $(15,16)$. Using ISEL, in which digoxigenin-dUTP is added to free $3^{\prime}$ ends of DNA with terminal deoxynucleotidyl transferase in nuclei in tissue sections (32), we showed that many cells had damaged DNA (Fig. 2 ). For the ISEL reaction, we used 4 min of incubation with alkaline phosphatase substrate. Longer times of incubation did not increase the number of reactive cells but there was a large increase in the amount of reaction product per cell.

On the other hand, the pattern of proliferating cells detected by the MIB-1 antibody against the Ki-67 proliferationspecific antigen was completely different; a few Ki-67-positive cells were scattered in the periphery of the cortex and in a somewhat higher concentration in a few parts of the midline of the gland. Most did not appear to be adrenocortical cells. The greatest accumulation detected, adjacent to a venule in the center of the gland, is shown in Fig. 2.

Considering possible origins of p21 and p53 immunoreactivity and DNA damage observed here, we hypothesized that ischemia/reperfusion injury might have been partially responsible. Because heat shock protein 70 (hsp70) has been shown to be elevated in cells of the heart, central nervous system, and kidney after ischemic injury (38-40), we examined hsp70 in adrenal glands with p21 expression. Fig. 3 shows a high level of cytoplasmic hsp70 immunoreactivity which extended throughout the cortex; however, the medulla was not stained.

No adrenal tissue specimens other than that shown in Figs. 2 and 3 showed such extensive immunostaining for p21, p53, and hsp70, or reaction with ISEL, but other adrenal tissue specimens which exhibited p21 mRNA also showed groups of p21-, p53-, hsp70- and ISEL-positive cells (Fig. 4), although 

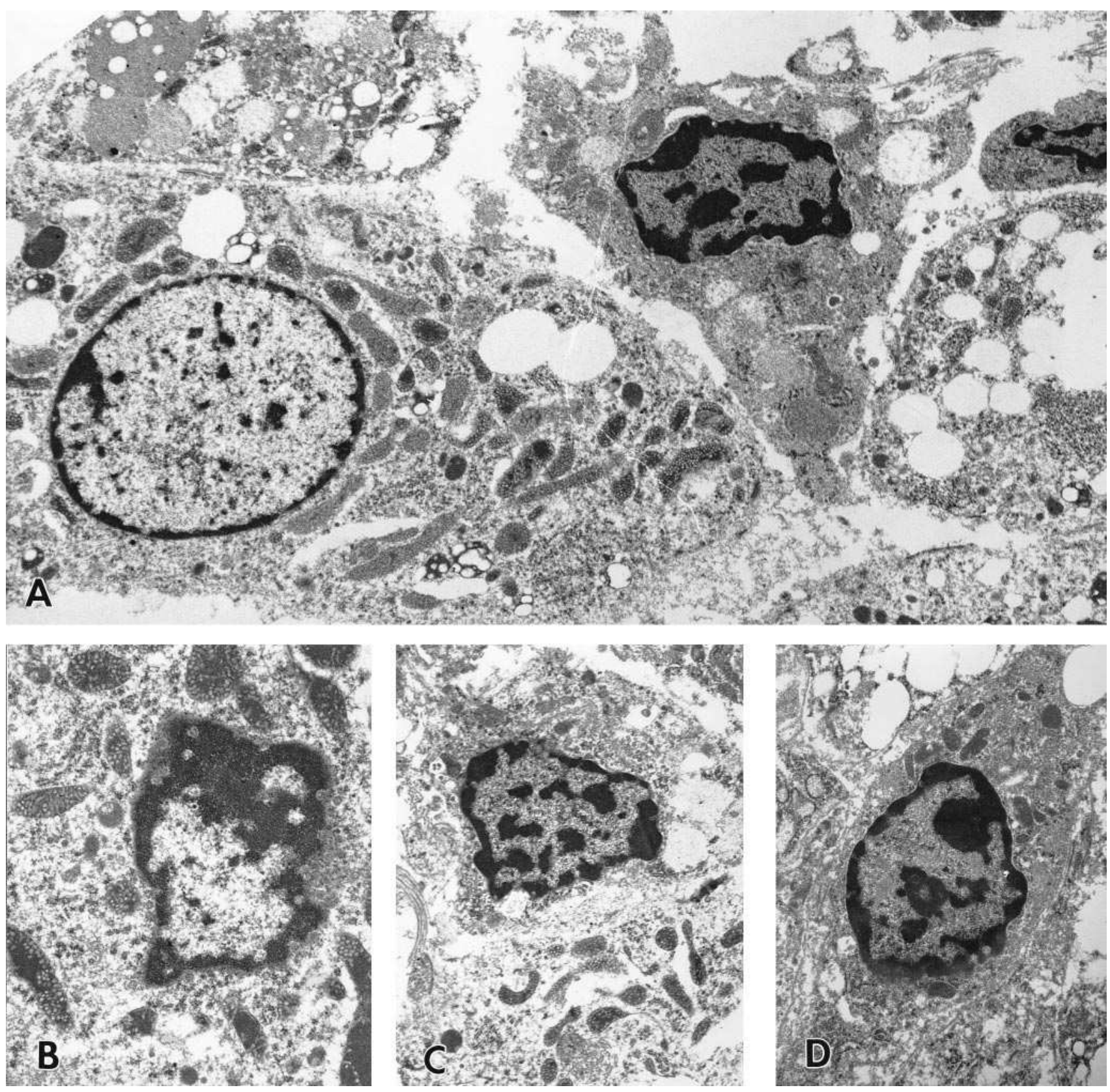

Figure 5. Ultrastructure of adrenocortical cells in human adrenal glands with p21/p53/ISEL-positive cells. $A-C$ are from a 63-yr-old donor (see Fig. 4) and $D$ is from an 8-yr-old donor (see Figs. 2 and 3). $A$ shows a cell with normal appearance on the left and a cell with shrunken nucleus and chromatin condensation on the right. The presence of mitochondria with tubulovesicular cristae identifies both cells as adrenocortical cells. $B-D$ show individual cells with similar nuclear and mitochondrial morphology. Original magnifications: $A, \times 18,000 ; B, \times 25,000 ; C$ and $D$, $\times 18,000$.

this reactivity was in these cases always focal, mostly in areas which appear to be nodules (41). Such specimens were from donors of various ages. Other tissue specimens that did not have significant p21 mRNA also had an absence of p21 immunoreactivity and did not show p53 and hsp70 immunoreactivity or ISEL-detected DNA damage and were from both younger and older donors (Fig. 4).

We investigated the possibility that ISEL-positive cells in human adrenal glands were undergoing apoptosis. When fragments of tissue from two glands with p21/p53/ISEL-positive cells were examined by electron microscopy, many nuclei with the appearance shown in Fig. 5 were observed. These nuclei exhibited shrinkage to various extents and showed accumulation of condensed chromatin at the nuclear membrane, an appearance typical of the early stages of apoptosis $(42,43)$. Mitochondria in these cells were intact and had tubulovesicular cristae, thus identifying them as adrenocortical cells (44). A similar nuclear morphology was apparent by fluorescence microscopy after sections were stained with the DNA-binding dye DAPI (Fig. 6). Additionally, inspection of sections labeled with anti-p53, anti-p21 antibodies, and ISEL-positive cells showed that the most intense nuclear staining in all three cases 

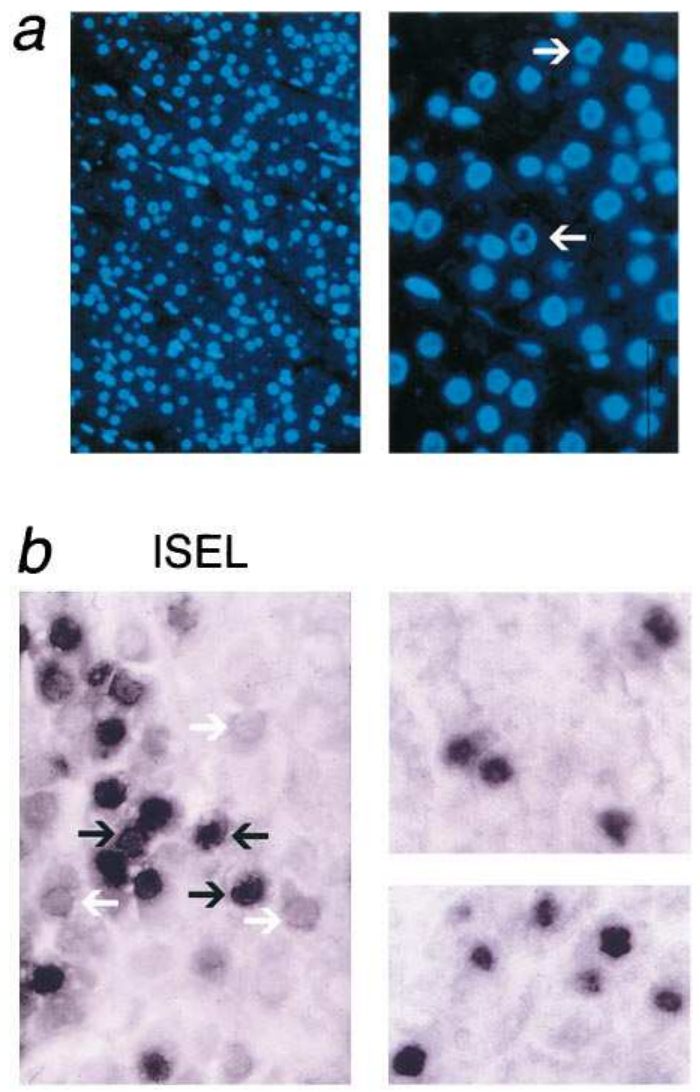

p21

p53

Figure 6. Nuclei with features of apoptotic morphology in human adrenal gland; 8-yr-old donor (see Figs. 2 and 3). (a) DAPI fluorescence. On the left, cords of adrenocortical cells are visible with many showing altered nuclear morphology; at higher magnification on the right two cells that show chromatin condensation apparently similar to that seen by electron microscopy in Fig. 5 are indicated by arrows. (b) p21, p53 immunoreactivity, and ISEL in cells with altered nuclear morphology. For ISEL, three heavily labeled cells with altered nuclear morphology are indicated by black arrows. Three lightly stained cells with normal nuclear appearance are indicated by white arrows. Original magnifications: $a, \times 200$ and $\times 630 ; b, \times 1,000$.

was in cells with the same altered nuclear morphology, although some other cells with no or minimal nuclear changes were also stained (Fig. 6).

The pattern of p53, p21, and hsp70 associated with apoptotic cells suggested that these tissues had sustained cellular injury in vivo at some time before excision of the gland from the body. We hypothesized that the initial cellular injury activated p53, which then increased the transcription of p21 (1) and initiated the process of apoptosis (15). Evidently it was not possible to test this hypothesis directly in the case of human adrenal glands. However, we sought to test it in a rat model, using ischemia/reperfusion, one of the more likely sources of in vivo damage to human adrenal glands in surgical patients and organ donors.

First, we evaluated the level of expression of p21 mRNA in adrenal glands from untreated rats. Mouse p21 cDNA, used as a probe for rat RNA, hybridized to a $2.3-\mathrm{kb}$ band similar in size to that reported for mouse, human, and bovine p21 mRNA $(1,2,5,18,45)$. Fig. 7 shows that both the cortex and the medulla of the rat adrenal gland express only very low levels of p21 mRNA in vivo, whereas the expression of differenti-

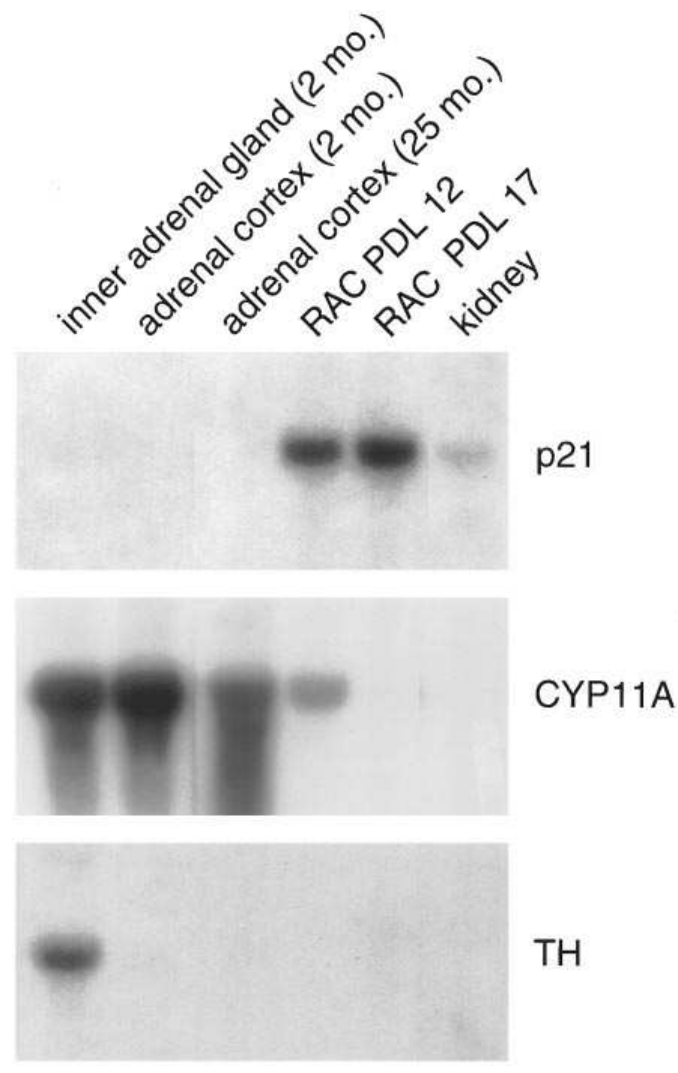

Figure 7. Northern blot showing p21 expression in rat tissues and in cultured rat adrenocortical cells $(R A C)$ at different PDLs. Tissues were obtained from the indicated ages of animals. Inner adrenal gland refers to a preparation of mixed medulla and cortex. The blot was probed successively with mouse p $21 \mathrm{cDNA}$, rat CYP11A (cholesterol side-chain cleavage) cDNA, and rat tyrosine hydroxylase $(\mathrm{TH})$ cDNA probes.

ated function genes (cholesterol side-chain cleavage [CYP11A] and tyrosine hydroxylase) was as expected for the two parts of the gland. p21 mRNA was not detected in several adrenal cortex specimens from both young (1-2-mo-old) and old (15-25mo-old) rats, whereas the kidney showed a low but detectable level, consistent with a previous report in the mouse (45). As previously shown for human and bovine adrenocortical cells, rat adrenocortical cells had much higher levels of p21 mRNA when placed in culture, particularly in cells that were close to replicative senescence (PDL 17). Rat adrenocortical cells have a total proliferative potential of $\sim 20$ population doublings (24) and reproducibly senesce without spontaneous transformation. CYP11A mRNA was low in the cultured adrenocortical cells, which were not exposed to inducers such as cyclic AMP (24) in this experiment.

In rats subjected to $30 \mathrm{~min}$ of adrenal gland ischemia followed by $8 \mathrm{~h}$ of recovery, p21 was induced in the adrenal glands as evidenced by Northern blotting and immunohistochemistry (Fig. 8). p21 expression was accompanied by appearance of nuclear p53, whereas no p53 was detected in control specimens. Moreover, a large number of cells in the ischemic gland showed DNA damage by the ISEL method, but there was no ISEL staining in the sham-operated controls. In this case, the positive ISEL reaction was observed using a longer time of incubation with alkaline phosphate substrate 

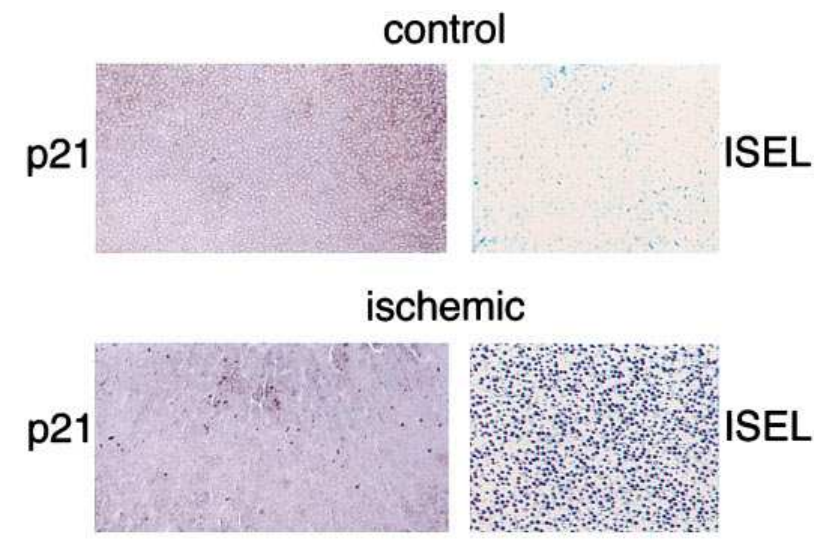

p21
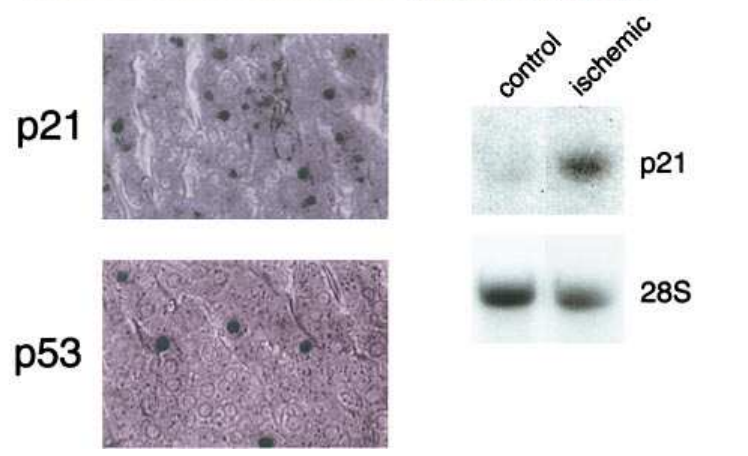

$28 S$

Figure 8. Ischemia/reperfusion effects in the rat adrenal gland. Adrenal glands were obtained from sham-operated control animals or from animals subjected to adrenal ischemia and reperfusion as described in the text. Tissues were fixed and processed as described. The upper photomicrographs (original magnification $\times 100$ ) show $\mathrm{p} 21$ immunoreactivity and staining by the ISEL procedure. Below are $\times 400$ details of p21 and p53 immunoreactivity in the ischemic gland. Additionally, a Northern blot showing p 21 mRNA levels is shown.

(30 min) than that used for detection in the human gland in Fig. 2 (4 min). When $4 \mathrm{~min}$ of incubation was used, the ischemic glands showed a much smaller number of ISEL-positive cells, similar to the number of p21- and p53-reactive cells.

Although the ischemia/reperfusion experiments indicated that induction of p21 can occur in the adrenal gland in vivo, we were also concerned with the possible induction of p21 in human tissues removed from the body but remaining under conditions where tissue damage and p21 induction in living cells were still possible. This concern arose because of our previous finding that enzymatic/mechanical dissociation of bovine adrenocortical cells from intact cortex is sufficient to induce p21 mRNA and protein within $3 \mathrm{~h}$ (18). To test this possibility, fragments of bovine adrenocortical tissue were either fixed immediately after removal from the animal, within $20 \mathrm{~min}$ of death, or were incubated at $37^{\circ} \mathrm{C}$ in culture medium for $16 \mathrm{~h}$. Tissue fixed immediately after death of the animal did not have detectable p21 expression by Northern blotting or immunohistochemistry, in confirmation of our previous observations (18). After incubation for $16 \mathrm{~h}$ in vitro a zone of nuclear p21 immunoreactivity was observed (Fig. 9). However, in this case, p21 expression was restricted to the surface of the fragments, which presumably had sufficient nutrients and oxygen for the cells to remain viable, and did not extend to the inner part of the tissue. a
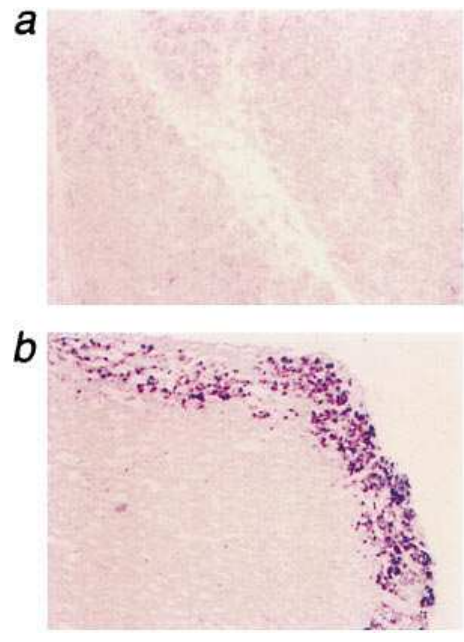

Figure 9. Expression of $\mathrm{p} 21$ in bovine adrenocortical tissue in vitro. Fragments of bovine adrenocortical tissue were fixed immediately after death of the animal $(a)$ or were fixed after overnight incubation in culture medium as described in the text $(b)$. Immunoreactivity with a monoclonal antibody against human p21 (EA10) is shown $(\times 100)$.

\section{Discussion}

Expression of the cell cycle inhibitor $\mathrm{p} 21^{\mathrm{WAF} 1 / \mathrm{CIP} 1 / \mathrm{SDI} 1}$ in human adrenal glands was highly variable. We hypothesize that this variability results from the different clinical histories of donors before removal of the glands. The patterns of $\mathrm{p} 21, \mathrm{p} 53$, and hsp70 immunoreactivity, DNA damage, and apoptosis in human adrenal glands observed here suggest the occurrence of a specific pathophysiological process before excision of the glands from the body and do not appear to result from artifactual postmortem changes. All glands studied here had uninterrupted circulation at the time of excision, either during kidney surgery or at the time of removal of the adrenal and kidney for potential transplantation. Although we have also observed varying levels of p21 immunoreactivity in human adrenal glands obtained at autopsy (our unpublished observations), these specimens were not included in the present data. The possibility of postmortem processes must be considered because we also observed that bovine adrenocortical tissue fragments, initially negative for p21 expression immediately after death of the animal, express p21 after incubation in vitro at $37^{\circ} \mathrm{C}$. Considered together with our previous observation that p21 is induced in bovine adrenocortical cells by the process of dissociation from the intact tissue (18), these data demonstrate the evident potential for postmortem tissue expression of p21. However, human adrenal tissue specimens show p21-positive cells within the inner part of the cortex at the venous end of the capillary bed or within nodular structures, rather than at the cut surface as observed in the bovine tissue fragments. Moreover, postmortem induction of p21 in human adrenal glands would require incubation of the tissue at close to physiological temperature for several hours, a possibility inconsistent with the actual handling of the glands studied. Thus, although we cannot definitively rule out postmortem changes, the fact that expression of p21 is in highly specific patterns in the human adrenal gland and the fact that $\mathrm{p} 21$ can be induced in the rat adrenal gland by ischemia/reperfusion without in vitro incubation strongly suggest that $\mathrm{p} 21$ can be induced in the human adrenal by pathophysiological events in vivo.

p21 is likely to be expressed in human tissues under conditions where damage to DNA or other cellular components provides a signal for $\mathrm{p} 21$ expression, presumably as part of the mechanism whereby p53, acting as "guardian of the genome," 
acts to limit tissue damage by allowing time for repair or by eliminating damaged cells by apoptosis (14, 46-48). The present experiments add ischemia/reperfusion damage to the in vivo events that potentially could activate this pathway. Ischemia/reperfusion is associated with an early phase of DNA damage, including oxidative damage products and strand breaks, and later phases involving both apoptosis and necrosis, dependent on the severity of the ischemic damage (49-54). Accumulation of p53 and hsp70 has been observed in some models of ischemia $(52,55)$. Presumably, the extent of the damage determines whether the tissue response comprises only repair and restoration of normal structure and function or includes some apoptosis, thereby eliminating damaged cells, or proceeds to necrosis, associated with functional failure of the tissue and slow repair. The second of these three possibilities seems likely in the adrenal glands observed here. As evidenced by the occurrence of cells with apoptotic morphology, the end point of the damage appears to be cell death, although the possibility that other cells have repairable DNA damage cannot be excluded. Although p53-dependent apoptosis has been established in many systems $(14,46,48,56)$, a role for $\mathrm{p} 21$ in this process is not clear. It has been suggested that cell cycle arrest via expression of p21 is an early event in the sequence by which activation of p53 leads to cell death (57), but mice with a p21 null mutation have unimpaired p53-dependent apoptosis (58).

Apoptosis has been described in the rat adrenal cortex when the tissue is deprived of its trophic hormone, ACTH, either by hypophysectomy or by glucocorticoid administration $(42,59,60)$. It is unlikely that the present observations are related to withdrawal of trophic hormone, because first, surgical stress causes elevated plasma ACTH (44); second, in the rat, the tissue reaction observed here was much more rapid than apoptosis observed after ACTH withdrawal, which reaches a maximal level after several days $(59,60)$; and third, p53-dependent apoptosis does not appear to be involved in normal tissue remodeling and growth, as evidenced by unimpaired development and homeostasis of organ growth in p53 null mice (61).

However, the p53- and p21-associated process of reaction to injury of the adrenal cortex may be related to several previous experimental and clinical observations on the pathophysiology of the adrenal gland. Restraint stress in rats causes damage to the adrenal cortex and lipofuscin accumulation (62) and accumulation of hsp70 (63). Damage may also be caused by bacterial toxins (64), toxic chemicals with adrenolytic properties (65), anticoagulants, and ill-defined factors during and after surgery (66). Waterhouse-Friderichsen syndrome, involving adrenal hemorrhage and adrenal failure, is a severe form of this damage (44). However, milder forms of this process, not associated with overt adrenal failure and glucocorticoid deficiency, are increasingly recognized as a consequence of the more frequent use of MRI and CT scanning (66). The less severe reaction of the adrenal cortex to surgical stress commonly involves a selective decrease in the production of adrenal androgen precursors (67). These steroids are synthesized by cells on the venous end of the capillary bed, the zona reticularis, and so might be particularly susceptible to ischemic injury (68). The demonstration of p21 and p53 in adrenocortical nodules supports the previous hypothesis that these lesions, which increase in number with age, result from local vascular abnormalities $(41,69)$. p53- and p21-associated apoptosis in the adrenal cortex may be a mechanism common to several patho- physiological processes associated with functional changes in this tissue over the life span in humans.

\section{Acknowledgments}

We are grateful to Donna Turner and Ralph Nichols for assistance with electron microscopy.

This work was supported by National Institutes of Health grants AG06108 and AG12287.

\section{References}

1. El-Deiry, W.S., T. Tokino, V.E. Velculescu, D.B. Levy, R. Parsons, J.M. Trent, D. Lin, W.E. Mercer, K.W. Kinzler, and B. Vogelstein. 1993. WAF1, a potential mediator of p53 tumor suppression. Cell. 75:817-825.

2. Harper, J.W., G.R. Adami, N. Wei, K. Keyomarsi, and S.J. Elledge. 1993. The p21 Cdk-interacting protein Cip1 is a potent inhibitor of G1 cyclin-dependent kinases. Cell. 75:805-816.

3. Gu, Y., C.W. Turck, and D.O. Morgan. 1993. Inhibition of CDK2 activity in vivo by an associated 20K regulatory subunit. Nature (Lond.). 366:707-710.

4. Xiong, Y., G.J. Hannon, H. Zhang, D. Casso, R. Kobayashi, and D. Beach. 1993. p21 is a universal inhibitor of cyclin kinases. Nature (Lond.). 366: 701-704.

5. Noda, A., Y. Ning, S.F. Venable, O.M. Pereira-Smith, and J.R. Smith 1994. Cloning of senescent cell-derived inhibitors of DNA synthesis using an expression screen. Exp. Cell Res. 211:90-98.

6. Smith, J.R. 1992. Inhibitors of DNA synthesis derived from senescent human diploid fibroblasts. Exp. Gerontol. 27:409-412.

7. Johnson, M., D. Dimitrov, P.J. Vojta, J.C. Barrett, A. Noda, O.M. Pereira-Smith, and J.R. Smith. 1994. Evidence for a p53-independent pathway for upregulation of SDI1/CIP1/WAF1/p21 RNA in human cells. Mol. Carcinog. 11:59-64.

8. Dulic, V., W.K. Kaufmann, S.J. Wilson, T.D. Tlsty, E. Lees, J.W. Harper, S.J. Elledge, and S.I. Reed. 1994. p53-dependent inhibition of cyclin-dependent kinase activities in human fibroblasts during radiation-induced G1 arrest. Cell. 76:1013-1023

9. Michieli, P., M. Chedid, D. Lin, J.H. Pierce, W.E. Mercer, and D. Givol 1994. Induction of WAF1/CIP1 by a p53-independent pathway. Cancer Res. 54: 3391-3395.

10. Slebos, R.J.C., M.H. Lee, B.S. Plunkett, T.D. Kessis, B.O. Williams, T. Jacks, L. Hedrick, M.B. Kastan, and K.R. Cho. 1994. p53-dependent G1 arrest involves pRB-related proteins and is disrupted by the human papilloma virus 16 E7 oncoprotein. Proc. Natl. Acad. Sci. USA. 91:5320-5324.

11. Sheikh, M.S., X.-S. Li, J.-C. Chen, Z.-M. Shao, J.V. Ordonez, and J.A. Fontana. 1994. Mechanisms of regulation of WAF1/Cip1 gene expression in human breast carcinoma: role of p53-dependent and independent signal transduction pathways. Oncogene. 9:3407-3415.

12. Shivji, M.K.K., S.J. Grey, U.P. Strausfeld, R.D. Wood, and J.J. Blow. 1994. Cip1 inhibits DNA replication but not PCNA-dependent nucleotide excision-repair. Curr. Biol. 4:1062-1068.

13. Elledge, S.J., and J.W. Harper. 1994. Cdk inhibitors: on the threshold of checkpoints and development. Curr. Opin. Cell Biol. 6:847-852.

14. Canman, C.E., C.-Y. Chen, M.-H. Lee, and M.B. Kastan. 1994. DNA damage responses: p53 induction, cell cycle perturbations, and apoptosis. Cold Spring Harbor Symp. Quant. Biol. 59:277-286.

15. El-Deiry, W.S., J.W. Harper, P.M. O'Connor, V.E. Velculescu, C.E. Canman, J. Jackman, J.A. Pietenpol, M. Burrell, D.E. Hill, Y. Wang, et al. 1994. WAF1/CIP1 is induced in p53-mediated G1 arrest and apoptosis. Cancer Res. 54:1169-1174.

16. El-Deiry, W.S., T. Tokino, T. Waldman, J.D. Oliner, V.E. Velculescu, M. Burrell, D.E. Hill, E. Healy, J.L. Rees, S.R. Hamilton, et al. 1995. Topological control of $\mathrm{p} 21^{\mathrm{WAF} 1 / \mathrm{CIP} 1}$ expression in normal and neoplastic tissues. Cancer Res. 55:2910-2919.

17. Parker, S.B., G. Eichele, P. Zhang, A. Rawls, A.T. Sands, A. Bradley, E.N. Olson, J.W. Harper, and S.J. Elledge. 1995. p53-independent expression of p21Cip1 in muscle and other terminally differentiating cells. Science (Wash. DC). 267:1024-1027.

18. Yang, L., V.V. Didenko, A. Noda, T.A. Bilyeu, G.D. Darlington, J.R Smith, and P.J. Hornsby. 1995. Increased expression of p21 $1^{\text {Sdi1 }}$ in adrenocortical cells when they are placed in culture. Exp. Cell Res. 221:126-131.

19. Hornsby, P.J. 1985. The regulation of adrenocortical function by control of growth and structure. In Adrenal Cortex. D.C. Anderson and J.S.D. Winter, editors. Butterworth, London. 1-31.

20. Ponten, F., B. Berne, Z.-P. Ren, M. Nister, and J. Ponten. 1995. Ultraviolet light induces expression of p53 and p21 in human skin: effect of sunscreen and constitutive 21 expression in skin appendages. J. Invest. Dermatol. 105: 402-406.

21. Healy, E., N.J. Reynolds, M.D. Smith, D. Harrison, E. Doherty, C. 
Campbell, and J.L. Rees. 1995. Up-regulation of $\mathrm{p} 21^{\mathrm{WAF} 1 / \mathrm{CIP} 1}$ in psoriasis and after the application of irritants and tape stripping. J. Invest. Dermatol. 105:274279.

22. Southard, J.H. 1995. Development and optimization of preservation solutions. In Cell Biology of Trauma. J.J. Lemasters and C. Oliver, editors. CRC Press, Boca Raton, FL. 289-297.

23. Hornsby, P.J., and J.M. McAllister. 1991. Culturing steroidogenic cells. In Methods in Enzymology, Vol. 206. M.R. Waterman and E.F. Johnson, editors. Academic Press, Inc., San Diego. 371-380.

24. McAllister, J.M., and P.J. Hornsby. 1987. Improved clonal and nonclonal growth of human, rat, and bovine adrenocortical cells in culture. In Vitro Cell. \& Dev. Biol. 23:677-685.

25. Hornsby, P.J., and S.E. Harris. 1987. Oxidative damage to DNA and replicative life span in cultured adrenocortical cells. Exp. Cell Res. 168:203-217.

26. Bradshaw, K.D., M.R. Waterman, R.T. Couch, E.R. Simpson, and M.X Zuber. 1987. Characterization of complementary deoxyribonucleic acid for human adrenocortical $17 \alpha$-hydroxylase: a probe for analysis of $17 \alpha$-hydroxylase deficiency. Mol. Endocrinol. 1:348-354.

27. Oonk, R.B., J.S. Krasnow, W.G. Beattie, and J.S. Richards. 1989. Cyclic AMP-dependent and -independent regulation of cholesterol side chain cleavage cytochrome $\mathrm{P}-450(\mathrm{P}-450 \mathrm{scc})$ in rat ovarian granulosa cells and corpora lutea. cDNA and deduced amino acid sequence of rat P-450scc. J. Biol. Chem. 264:21934-21942.

28. Brown, E.R., G.T. Coker III, and K.L. O'Malley. 1987. Organization and evolution of the rat tyrosine hydroxylase gene. Biochemistry. 26:5208-5212.

29. Naseeruddin, S.A., and P.J. Hornsby. 1990. Regulation of $11 \beta$ - and $17 \alpha-$ hydroxylases in cultured bovine adrenocortical cells: cyclic adenosine $3^{\prime}, 5^{\prime}$ monophosphate, insulin-like growth factor-I, and activators of protein kinase C. Endocrinology. 127:1673-1681.

30. Zhu, L., E. Harlow, and B.D. Dynlacht. 1995. p107 uses a p21CIP1related domain to bind cyclin/cdk2 and regulate interactions with E2F. Genes \& Dev. 9:1740-1752.

31. Gannon, J.V., R. Greaves, R. Iggo, and D.P. Lane. 1990. Activating mutations in p53 produce a common conformational effect. A monoclonal antibody specific for the mutant form. EMBO (Eur. Mol. Biol. Organ.) J. 9:15951602.

32. Gavrieli, Y., Y. Sherman, and S.A. Ben-Sasson. 1992. Identification of programmed cell death in situ via specific labeling of nuclear DNA fragmentation. J. Cell Biol. 119:493-501.

33. Aharoni, D., A. Dantes, M. Oren, and A. Amsterdam. 1995. cAMPmediated signals as determinants for apoptosis in primary granulosa cells. Exp. Cell Res. 218:271-282.

34. Kovacs, K., R. Carroll, and E. Tapp. 1966. Temporary ischaemia of the rat adrenal gland. J. Pathol. Bacteriol. 91:235-240.

35. Dobbie, J.W., and T. Symington. 1966. The human adrenal gland with special reference to the vasculature. J. Endocrinol. 34:479-489.

36. Di Leonardo, A., S.P. Linke, K. Clarkin, and G.M. Wahl. 1994. DNA damage triggers a prolonged p53-dependent G1 arrest and long-term induction of Cip1 in normal human fibroblasts. Genes \& Dev. 8:2540-2551.

37. Li, Y., C.W. Jenkins, M.A. Nichols, and Y. Xiong. 1994. Cell cycle expression and p53 regulation of the cyclin-dependent kinase inhibitor p21. Oncogene. 9:2261-2268.

38. Mehta, H.B., B.K. Popovich, and W.H. Dillmann. 1988. Ischemia induces changes in the level of mRNAs coding for stress protein 71 and creatine kinase M. Circ. Res. 63:512-517.

39. Brown, I.R. 1990. Induction of heat shock (stress) genes in the mammalian brain by hyperthermia and other traumatic events: a current perspective. $J$. Neurosci. Res. 27:247-255.

40. Lovis, C., F. Mach, Y.R. Donati, J.V. Bonventre, and B.S. Polla. 1994. Heat shock proteins and the kidney. Renal Fail. 16:179-192.

41. Neville, A.M. 1978. The nodular adrenal. Invest. Cell Pathol. 1:99-111.

42. Wyllie, A.H., J.F.R. Kerr, and A.R. Currie. 1980. Cell death: the significance of apoptosis. Int. Rev. Cytol. 68:251-280.

43. Kerr, J.F.R., C.M. Winterford, and B.V. Harmon. 1994. Morphological criteria for identifying apoptosis. In Cell Biology: A Laboratory Handbook. Vol. 1. J.E. Celis, editor. Academic Press, Inc., San Diego. 319-329.

44. Neville, A.M., and M.J. O'Hare. 1982. The Human Adrenal Cortex. Pathology and Biology - An Integrated Approach. Springer-Verlag, Berlin. 45. Huppi, K., D. Siwarski, J. Dosik, P. Michieli, M. Chedid, S. Reed, B.
Mock, D. Givol, and J.F. Mushinski. 1994. Molecular cloning, sequencing, chromosomal localization and expression of mouse p21 (Waf1). Oncogene. 9:30173020 .

16.

46. Lane, D.P. 1992. p53, guardian of the genome. Nature (Lond.). 358:15-

47. Pines, J. 1994. Cell cycle. p21 inhibits cyclin shock. Nature (Lond.). 369: $520-521$.

48. Wyllie, A.H. 1994. Apoptosis. Death gets a brake. Nature (Lond.). 369 : 272-273.

49. Floyd, R.A., and J.M. Carney. 1992. Free radical damage to protein and DNA: mechanisms involved and relevant observations on brain undergoing oxidative stress. Ann. Neurol. 32(Suppl.):S22-S27.

50. Sato, T., K. Koyama, T. Takemasa, S. Yoshida, Y. Sato, S. Omokawa, and N.J. Lygidakis. 1992. Damage and repair of hepatocyte nuclear DNA after hepatic inflow occlusion. Hepato-gastroenterology. 39:252-256.

51. Schumer, M., M.C. Colombel, I.S. Sawczuk, G. Gobe, J. Connor, K.M. O'Toole, C.A. Olsson, G.J. Wise, and R. Buttyan. 1992. Morphologic, biochemical, and molecular evidence of apoptosis during the reperfusion phase after brief periods of renal ischemia. Am. J. Pathol. 140:831-838.

52. Li, Y., M. Chopp, Z.G. Zhang, C. Zaloga, L. Niewenhuis, and S. Gautam. 1994. p53-immunoreactive protein and p53 mRNA expression after transient middle cerebral artery occlusion in rats. Stroke. 25:849-856.

53. MacManus, J.P., I.E. Hill, Z.G. Huang, I. Rasquinha, D. Xue, and A.M. Buchan. 1994. DNA damage consistent with apoptosis in transient focal ischaemic neocortex. Neuroreport. 5:493-496.

54. Gottlieb, R.A., K.O. Burleson, R.A. Kloner, B.M. Babior, and R.L. Engler. 1994. Reperfusion injury induces apoptosis in rabbit cardiomyocytes. $J$. Clin. Invest. 94:1621-1628.

55. Chopp, M. 1993. The roles of heat shock proteins and immediate early genes in central nervous system normal function and pathology. Curr. Opin. Neurol. Neurosurg. 6:6-10.

56. King, K.L., and J.A. Cidlowski. 1995. Cell cycle and apoptosis: common pathways to life and death. J. Cell. Biochem. 58:175-180.

57. Meikrantz, W., and R. Schlegel. 1995. Apoptosis and the cell cycle. J. Cell. Biochem. 58:160-174.

58. Deng, C., P. Zhang, J.W. Harper, S.J. Elledge, and P. Leder. 1995. Mice lacking p21 $1^{\mathrm{CIP} 1 / \mathrm{WAF} 1}$ undergo normal development, but are defective in G1 checkpoint control. Cell. 82:675-684.

59. Wyllie, A.H., J.F. Kerr, I.A. Macaskill, and A.R. Currie. 1973. Adrenocortical cell deletion: the role of ACTH. J. Pathol 111:85-94.

60. Ceccatelli, S., A. Diana, M.J. Villar, and P. Nicotera. 1995. Adrenocortical apoptosis in hypophysectomized rats is selectively reduced by ACTH. Neuroreport. $6: 342-344$

61. Donehower, L.A., M. Harvey, B.L. Slagle, M.J. McArthur, C.A. Montgomery, Jr., J.S. Butel, and A. Bradley. 1992. Mice deficient for p53 are developmentally normal but susceptible to spontaneous tumours. Nature (Lond.). 356:215-221.

62. Ryzhavskii, B.I. 1978. Izmenenie kory nadpochechnikov krys pri stresse posle udaleniia gipofiza, shchitovidnoi zhelezy i iaichka. Arkh. Anat. Gistol. Embriol. 74(4):40-46.

63. Blake, M.J., R. Udelsman, G.J. Feulner, D.D. Norton, and N.J. Holbrook. 1991. Stress-induced heat shock protein 70 expression in adrenal cortex: an adrenocorticotropic hormone-sensitive, age-dependent response. Proc. Natl. Acad. Sci. USA. 88:9873-9877.

64. Siegel, L.M., S.K. Grinspoon, G.J. Garvey, and J.P. Bilezikian. 1994 Sepsis and adrenal function. Trends Endocrinol. Metab. 5:324-328.

65. Giampaolo, C., A.T. Gray, R.A. Olshen, and S. Szabo. 1991. Predicting chemically induced duodenal ulcer and adrenal necrosis with classification trees. Proc. Natl. Acad. Sci. USA. 88:6298-6302.

66. Rao, R.H. 1995. Bilateral massive adrenal hemorrhage. Med. Clin. N. Am. 79:107-129.

67. Lindh, A., K. Carlstrom, J. Eklund, and N. Wilking. 1992. Serum steroids and prolactin during and after major surgical trauma. Acta Anaesthesiol. Scand. 36:119-124.

68. Hornsby, P.J. 1995. Biosynthesis of DHEAS by the human adrenal cortex and its age-related decline. Ann. NY Acad. Sci. 774:29-46.

69. Dobbie, J.W. 1969. Adrenocortical nodular hyperplasia: the aging adrenal. J. Pathol. 99:1-18. 